\title{
Behavioral and Hematological Response of Clarias gariepinus juvenile exposed to Acute concentrations of Aqueous Extract of Siam Weed (Chloromolaena odorata) leaf as Anesthetic agent.
}

\author{
*Iheanacho Stanley Chidi $^{1}$ and Nworu Shedrack ${ }^{2}$ \\ ${ }^{1}$ Department of Fisheries and Aquaculture, Federal University Ndufu Alike Ikwo, Ebonyi State, \\ Nigeria \\ ${ }^{2}$ Department of Fisheries and Aquaculture, Ebonyi State University Abakaliki, Ebonyi State, \\ Nigeria \\ Corresponding author: stanley.iheanacho@funai.edu.ng,+2348063279905
}

\begin{abstract}
This experiment was carried out to investigate the effect of Siam Weed (chloromelena odorata) on the heamatology of Clarias gariepinus juvenile. A total of one hundred and fifty (150) juvenile of Clarias gariepinus were randomly assigned to different concentrations of $C$. odorata leave aqueous extract in a completely randomize design (CRD). The concentrations were 50mg/l, $100 \mathrm{mg} / 1,150 \mathrm{mg} / 1,200 \mathrm{mg} / \mathrm{l}$. Distilled water $(0.00 \mathrm{mg} / \mathrm{l})$ was used as the control. The fish exhibited stressful behavior which was higher as the concentration of Chromolaena odorata leave extract increased. There was a gradual decrease with time until a state of calmness, which was subsequently followed by death. The effect on $96 \mathrm{hr}$ exposed period was recorded and blood samples collected at $24 \mathrm{hr}$ and $96 \mathrm{hr}$ interval. Result on hematological parameters revealed significant difference $(\mathrm{P}<0.05)$ among treatments with increase in exposure time for all the blood parameters. $C$. odorata at increased concentrations affected the behavior and hematology of $C$. gariepinus.
\end{abstract}

Key word: Effects, C. odorata, Behavior, Hematology, C. gariepinus 


\section{Introduction}

Aquaculture is the fastest growing food producing sector in the world (Iheanacho et al. 2017) and has grown exponentially over the years especially in developing countries (James et al. 2001). Over the years, Aquaculture sector has encountered serious setbacks such as mortalities emanating from disease infections, mechanical injuries during transportation stress, sampling and sorting of fish (Romero et al. 2012). Anaesthetics are used with increasing frequency in aquaculture, mainly to reduce the stress and to prevent mechanical damage to fish during handling. Their use is particularly common in stripping, marking, biometry, tagging, artificial reproduction procedures and surgery, thus reducing stress-induced problems such as reduction in feeding and immune function (Ross and Ross 1999; Kolarova et al. 2007; Altun et al. 2009; Yildiz et al. 2013, Opiyo et al. 2013). The need to handle fish without impairing their health or commercial value has led to the development of many techniques to anaesthetize fish (Yildiz et al. 2013). Different anaesthetics act with various intensity driving fish into general anaesthesia, resulting in loss of consciousness, inhibition of reflex activity, and reduction in skeletal muscle tone (Hajek et al. 2006). Quick induction and recovery from anaesthesia is desirable in most cases (Marking and Meyer 1985; Stoskopf 1993).

However, long recovery time is desirable while collecting fish from the wild or where fish must be handled for a longer time in the laboratory. An ideal anaesthetic should possess several attributes such as; non-toxic, inexpensive, simple to administer and result in rapid induction and calm recovery (Pawar et al. 2011). It is of paramount importance to identify the effective dose of anaesthetic for specific fish species since response to the same anaesthetic vary depending on the concentration used and the species of fish (Tyler and Hawkins 1981; Pawar et al. 2011). Common fish anaesthetics include clove oil, sodium bicarbonate, carbon dioxide gas, 
metomidate, benzocaine, tricaine, methanesulphonate (MS-222), 2-phenoxylethanol and quinaldine (Massee et al. 1995; Palić et al. 2006). Regardless of the agent, the process of anaesthesia in fish develops in a similar way and runs in a progressive pattern.

Fish anaesthetics have positive effects on fish during transportation (Berka 1986), and handling or during surgical procedures (Marking and Meyer 1985). Selecting a suitable anesthetic depends mainly on its effectiveness in immobilizing fish with good recovery rates (Berka et al. 1986). The efficacy of aqueous extracts of some plants such as avocado pear as anaesthetic was been reported by Adebayo et al. (2010). Clove oil was used as anaesthetic on different species of fish (Taylor and Roberts 1999). Similarly, the effectiveness of mistletoe extract as anaesthetic was reported by Popoola et al. (2008).

In recent years there is preference for safe and environmentally friendly piscicides of plant origin than synthetic piscicides for catching fish and clearing pond. This is because ichthvotoxins are less expensive, biodegradable, readily available, easy to handle and save for mankind and the environment (Singh et al. 2010). The deliberate introduction of these plants extract in the aquatic ecosystems could eventually lead to physiological stress in aquatic organisms and ultimately reduction in aquatic productivity (Olufayo 2009). Plants parts have been shown to cause death of fish and changes in biochemical response of Channa punctatus (Tiwari and Singh 2004), haematological and histopathological effects on Clarias gariepinus (Omoniyi et al. 2002). Ubaha et al. (2012) reported decreased haemoglobin, haematocrit and erythrocytes when they studied the effect of Hypoestes forskalei leaf extract on the behavior of C. gariepinus. Ojutiku et al. (2013) studied the effect of acute concentration of cypermethrin on juveniles of $C$. gariepinus and reported that white blood cells (WBC), MCV, MCH, PCV and neutrophil levels increased, while RBC and lymphocytes reduced. Although anaesthetia of fish have positive effects on the 
fish during transportation and handling, some anaesthesias can pose dangerous problems to the fish organs and the blood parameters (Nicula et al. 2010). Knowledge of the haematological characteristics is an important tool that can be used as an effective and sensitive index to monitor physiological and pathological changes in fishes (Iheanacho et al. 2017).

Chromolaena odorata is a species of flowering shrub in the sunflower family, Asteraceae. It is native to North America, from Florida and Texasto Mexico and the Caribbean, and has been introduced to tropical Asia, west Africa, and parts of Australia. Common names include Siam Weed, Christmas Bush, and Common Floss Flower. It is sometimes grown as a medicinal and ornamental plant. It is used as a traditional medicine in Indonesia. The weed is used as herbal medicine (Ling et al. 2007) and produces characteristic smell when crushed. C. odorata have a complex mixture of flavonoid compounds including aurone, flavones and flavonol (Vital 2008). The flavonoid compounds possess antibacterial, antifungal and antiprotozoal properties (Vital and Rivera 2009).

Siamweed extract (SWE) accelerates hemostasis and wound healing (Phan et al. 2001). The presence of flavonoid an active chemical in C. odorata has been confirmed (Vital 2008). This compound is a potent antioxidant (Taleb-contini 2006).

This present study would form a baseline data for assessment of health status as per hematological indices of $C$. gariepinus exposed to acute concentration of aqueous extract of Siam weed (C. odorata) leaves under laboratory conditions.

\section{Materials and Methods}

\section{Area of the Study}


The study site was Federal University Ndufu Alike Ikwo, Ebonyi State. Ebonyi State is located approximately within latitude $6^{\circ} 20^{\prime} \mathrm{N}$ and longitude $8^{\circ} 06^{\prime} \mathrm{E}$ in the derived savannah of southEastern part of Nigeria at an elevation of $117 \mathrm{~m}$. The rainfall pattern is bimodal (April-July and September-November) with a short spell in August referred to as August break and annual rainfall of about $1,800-2,000 \mathrm{~mm}$. The average temperature is between $25^{\circ} \mathrm{C}$ in January, $34^{\circ} \mathrm{C}$ in June and $30^{\circ} \mathrm{C}$ in November.

\section{Procurement of the fish}

C. gariepinus juveniles weighing $50.02 \mathrm{~g}$ and total body length of $12.5 \mathrm{~cm}$ were procured from a reputable commercial fish Farm in Abakaliki, Ebonyi State. Fish were transported (1525minutes) with 50 litres gallon filled with fresh water from the farm, to wet laboratory and stocked in 200 litres capacity plastic tank. The fish were acclimatized to laboratory conditions $\left(25^{\circ} \mathrm{C}\right)$ for 10 days prior to the experiment. During the acclimation period the fish were fed twice daily commercial fish feed (Coppens, 4mm). Feeding of fish stopped two days prior to the start of the experiment.

\section{Collection, Indentification and Preparation of the plant}

Chromolaena odorata leaves sample was collected from the wild at Abakaliki and was identified by a botanist from the Department of Agriculture, Federal University Ndufu Alike Ikwo, Ebonyi State, Nigeria (Plate 1). Samples of Chromolaena odorata leaves were washed and shade-dried. It was then pulverised using mechanical blender. Precisely 100 grams of the fine powdered $C$. odorata was weighed using a weighing balance. The weighed sample was soaked in $200 \mathrm{mls}$ of distilled water contained in a conical flask and swirled. After 48hours, with interval stirring, the mixture was filtered using Whatman No.1 filter paper into a clean beaker. Extracts obtained was 
filtered with a membrane filter of pore size $0.45 \mathrm{ul}$ to obtain a sterile extract, the filtered extract was centrifuged using centrifugal machine and stored in an air-tight bottle at $4{ }^{\circ} \mathrm{C}$.

\section{Range-Finding}

A preliminary (range-finding) test as describe by Rahman et al. (2005) was conducted to determine the main experimental concentrations for the $C$. odorata leaves extract. The main experimental concentrations for the extract were determined based on 0-100\% of C. gariepinus in 24hours.

\section{Experimental design}

Total of 150 Clarias gariepinus juvenile were randomly assigned to five treatments with each treatment containing ten fish. Each treatment was replicated three times in a completely randomized design (CRD). A total of 15 plastic aquaria tanks (2m x $1.5 \mathrm{~m} \times 1 \mathrm{~m})$ were used for the experiment. Concentrations of $0.00,50,100,150$ and $200 \mathrm{ml} / 1$ of aqueous extracts of $C$. odorata known as treatments were prepared by weighing the aqueous extract and mixing it with cold water. Temperature and $\mathrm{pH}$ were determined at the start of the experiment and maintained optimal levels. The fish were exposed to $0.4 \mathrm{~g}$ (96 hr LC50) for 4 days (Okorie et al.1992) of the aqueous extract of Chromolaena odorata. A set of 10 fish were also simultaneously maintained in distilled water $(0.00 \mathrm{mg} / \mathrm{l})$ as the control each time the test was repeated.

\section{Collection of blood for Analysis}

At the end of day 24 and 96hr, two fish from each treatment were randomly taken for collection of blood. Holding the fish firmly, the operculum was lifted and blood collected by puncturing the cardiac into EDTA containers for determining haematological parameters.

\section{Haematological Analysis}


Blood parameters such red blood count (RBC), White blood cell (WBC), Hemoglobin content $(\mathrm{Hb})$ and Pack cell volume (PCV) were determined following the procedure of Dacie and Lewis (2011).

\section{Water quality parameters}

Water quality parameters such as temperature, dissolved oxygen and $\mathrm{pH}$ of the experimental tank water were determined using water quality kit (Pro. Kit, Flourida).

\section{Statistical Analysis}

The probit method of Finney (1971) was applied to estimate the 96 hour LC50. Results were reported as mean \pm standard error (SE) where appropriate. Mean values were compared with one-way analysis of variance (ANOVA) and considerable variations amongst sets were determined by Ducan multiple range test using SPSS for windows version 20. The degree of significant was set at $\mathrm{P}<0.05$.

\section{Result}

\section{Water parameter}

Mean values of water quality parameters for the different concentrations of $C$. odorata leaves extract and control media to which the test fish $C$. gariepinus were exposed over the 96hour exposure period are presented in Table 1.Mean values of the water temperature were not significantly ( $P \square 0.05)$ affected by the concentrations of $C$. odorata leaves extract. On the other hand, $\mathrm{pH}$ and dissolved oxygen significantly $(P<0.05)$ decreased as the concentrations of $C$. odorata leaves extract increased.

\section{Toxicity Bioassay (Mortality Response)}

Mortality in the three replicate of $C$. odorata leave extract concentrations at $96 \mathrm{hr}$ period varied significantly $(\mathrm{P}<0.05)$ in all the treatments and increased with increase in concentration (Table 
2). Mucos was copiously observed on the gills of the dead fish in all the treatments except the control which recorded no mortality. The Probit mortality data (Table 3) shows the mortality and time for $50 \%$ mortality (LC50).

\section{Haematological analysis}

Mean values for haematological examination of $C$. gariepinus exposed to acute concentration of aqueous extract of $C$. odorata leaf are presented in the respective figures (Fig.1,2,3 and 4). Result on hematological examination showed significant difference $((P<0.05)$ for all the parameters measured, when compared to the control.

\section{Discussions}

\section{Water Quality parameters}

Based on the present findings, changes in the water quality parameters showed that the $C$. odorata concentrations significantly affected the water quality especially dissolve oxygen and pH. Omoniyi et al. (2002), reported a decreased in water quality parameter values when Clarias gariepinus was exposed to sub lethal concentrations of tubbaco leaf extract. The variation in the reported result of monitored parameters could be associated with the exposure period and the level of $C$. odorata extract concentrations. The decline in $\mathrm{pH}$ with time could be due to the production of acidic metabolites (Haylor 1991). The acidic condition of the experimental tank water may have resulted to a decrease in the level of dissolved oxygen.

\section{Behavioural Characteristics}

The fish exhibited stressful behavior which was higher as the concentration of the solution increased. There was a gradual decrease with time until a state of calmness, which was subsequently followed by death. A similar pattern was reported by Fafioye et al. (2001) on Clarias gariepinus, and Rahman et al. (2002) for Clarias punctatus. The observed restlessness 
and uncoordinated swimming in bioassay media might be due to the effect chemical components

C. odorata leave extract. Akinbulumo (2005) reported that the fish showed a toxic reaction to Derris elliptica root powder by surfacing jaws and becoming stupefied.

\section{Heamatological Parameter}

Haematological indices are essential health indicators that reveal the health status of fish before and after an experiment (Iheanacho et al. 2017). The results indicated that PCV values reduced significantly ( $\mathrm{p} \square 0.05)$ with increased in concentration, although a mixed trend was observed for 24hrs hematological examination while a corresponding decrease in PCV values was observed for $96 \mathrm{hrs}$ compared to the control (Fig.4). Haemoglobin values for treated fish reduced significantly ( $\mathrm{p} \square 0.05$ ) for both $24 \mathrm{hrs}$ and $96 \mathrm{hrs}$ with respect to the control (Fig. 2). It was also observed that leucocytes counts increased significantly $(\mathrm{P}<0.05)$ (Fig. 3) while erythrocytes counts reduced significantly $(P<0.05)$ with increasing concentrations of Siam weed treated fish groups compared to the control for both periods (24hrs and 96hrs) (Fig. 1). Plants parts (Leaves root and bark) have been shown to cause death of fish and changes in biochemical response of Channa punctatus (Tiwari and Singh 2004), haematological and histopathological effects on Clarias gariepinus (Omoniyi et al., 2002). The effect of sublethal concentration of formothion has been reported by Singh and Srivastava (1999), with a significant decrease in haematocrit and haemoglobin concentration in Heteropneustes fossil. Ubaha et al. (2012) where gradual decrease in haemoglobin, pack cell volume and red blood cell count were observed when they studied the effect of Hypoestes forskalei leaf extract on the behavior of $C$. gariepinus. The significant increase in the values of white blood cell as the concentration of $C$. odorata leave extract increased could be attributed to the increase in leucocytes synthesis as a defense mechanism against the destruction of erythrocytes. Lymphocytes are the most numerous cells comprising the 
leucocytes, which function in the production of antibodies and chemical substances serving as a defense against infection (Iheanacho et al. 2017). Ojutiku et al. (2013) studied the effect of acute concentration of cypermethrin on juveniles of C. gariepinus and reported that white blood cells (WBC), MCV, MCH, PCV and neutrophil levels increased, while RBC and lymphocytes reduced.

\section{Conclusion}

Although the efficacy of plant materials in aquaculture have been effectively demonstrated, there is need to investigate their effects on fish health. Following the findings of the current study, we conclude that Siam weed (C. odorata) altered hematological parameters and affected negatively, the behavior of Clarias gariepinus.

\section{Acknowledgement}

Authors are grateful to family members

\section{REFERENCES}

Adebayo, O.T., Fasakin, E.A., and Popoola, O.M. 2010. Use of Acqeous Extracts of Avocado Pear, Pyrus Communis, Leaf as Anaesthetic in Gonadectomy of African Catfish, Clarias gariepinus. J. Applied Aquacult. 22(2): 117 - 122.

Akinbulumo, M.O. 2005. "Derrisel liptica as anaesthetic agent on Nile Tilapia, Oreochromis niloticus (Linne, 1758), Applied Trop. Agric,10, 24-27.

Altun, T., Bilgin, R., and Danabas, D. 2009. Effects of Sodium Bicarbonate on Anaesthesia of Common Carp, Cyprinus carpio Juveniles. Turkish J. Fish. Aquat. Sci., 9: 29-31. 
Berka, R. 1986. The transport of live fish: a review. EIFAC Technical Papers 48, FAO, Rome, $57 \mathrm{p}$.

Dacie, J.V., and Lewis, S.M. 2011. Practical Hematology. 11th edition, New York: Churchill Livingstone, 41p.

Hajek, G.J., Klyszejko B., and Dziaman R. 2006. The anaesthetic effect of clove oil on Common carp, Cyprinus carpio. Acta Ichthyologica, 36: 93-97.

Haylor, G.S. 1991. Controlled hatchery production of Clarias gariepinus (Burchell 1822) : growth and survival of fry at high stocking density," Aquacult Fish. Mgt. 4, 405-422.

Iheanacho, S.C., Ogunji, J.O., Ogueji, E.O., Nwuba, L.A., Nnatuanya, I.O., Ochang, S.N., Mbah, C.E., Usman, I.B., and Haruna, M. 2017. Comparative assessment of ampicillin antibiotic and ginger (Zingiber officinale) effects on growth, haematology and biochemical enzymes of Clarias gariepinus Juvenile. J. of Pharmacog. and Phytochem. 6(3): 761-767.

James, H., Tidwell, G., and Geoff, L. 2001. Fish as food: Aquaculture's contribution, The Euro. Mole. Biol. Organ. Report, 2(11): 958-963.

Kolarova, J., Velisek, J., Nepejchalova, L., Svobodova, Z., Kouri,l J., Hamackova, J., Machova J, Piackova, V, Hajslova, J, Holadova, K, Kocourek, V, Klimankova E, Modra H, Dobsikova, R, Groch, L, Novotny, L 2007. Anaesthetics for fish (in Czech). Research Institute of Fish Culture and Hydrobiology, Vodnany, Methods No. 77, 19 pp.

Ling. S.K., Pisar, M.M., and Man, S. 2007. Platelet-activating factor (PAF) receptor binding antagonist activity of the methanol extracts and isolated flavonoids from Chromolaena odorata (L.) King and Robinson. Biol. Pharm. Bull. 30(6): 1150- 1152. 
Marking, L.L., and Meyer, F.P. 1985. Are better anesthetics needed in fisheries? Fish., 10(6): 2-5

Massee, K.C., Rust, M.B., Hardy, R.W. and Stickney, R.R. 1995. The effectiveness of tricaine, quinaldine sulfate and metomidate as anaesthetics for larval fish. Aquacult., 134: 351359.

Nicula, M., Banatean-Dunea, I., Gergen, I., Harmanescu, M., Simiz E., Patruica S., Polen T., Marcu A., Lunca M., Szucs S. 2010. Effect of natural zeolite on reducing tissue bioaccumulation and cadmium antagonism related to some mineral micro- and macronutrients in Prussian carp (Carassius gibelio). AACL Bioflux 3, 171-179.

Ojutiku, R.O., Asuwaju, F.P., Kolo, R.J., Obande, R.A., and Agbelege, O.O. 2013. Haematological effect of acute concentration of cypermethrin on juveniles of Clarias gariepinus. Int' J. Eng. Sci. Invent. 2 (31): 96100.

Okorie, T.G., Ugwumba, A.O., Okon, A.O. 1992. Toxic and Sublethal effect of ethanolic extract of Piper guineense on Oreochromis niloticus (Linn) (Pisces: Cichlidae). J. Exp. App. Biol. 4(1-4):34-52.

Olufayo, M.O. 2009. Heamatological characteristics of Clarias gariepinus juveniles exposed to Derris elliptia root powder. Afr. J. Food Agric. Nutr. Dev., 9(3): 920-932.

Omoniyi, I. Agbon, A.O., and Sodunke, S.A. 2002. Effect of lethal and sub-lethal concentrations of tobacco (Nicotiana tobaccum) leaf dust extract on weight and haematological changes in Clarias gariepinus (Burchell, 1822.). J. App. Sci. Environ. Mgt., 6: 37-41. 
Opiyo, M.A., Ogello, E.O., and Charo Karisa, H. 2013. Effectiveness of Sodium Bicarbonate as an Anaesthetic for different sizes of Nile tilapia, Oreochromis niloticus Juveniles. Int J. Aquat. Sci., 4: 14-22.

Palic, D., Herolt, D.M., Andreason, C.B., Menzel, B.W. and Roth, J.W. 2006. Anaesthetic efficacy of tricaine methanesulfonate, metomidate and eugenol: Effects on plasma cortisol concentration and neutrophil function in fathead minnows, Pimephales promelas. Aquacult., 254: 675-685.

Pawar, H.B., Sanaye, S.V., Sreepada, R.A., Harish, V. Suryavanshi, U., Tanu and Ansari, Z.A. 2011. Comparative efficacy of four anaesthetic agents in the yellow seahorse, Hippocampus kuda. Aquacult. 311: 155-161.

Phan, T.T., Hughes, M.A., and Cherry, G.W. 2001. Effects of an aqueous extract from the leaves of Chromolaena odorata (Eupolin) on the proliferation of human keratinocytes and on their migration in an in vitro model of reepithelialization. Wound Repair and Regene 9(4): 305-313.

Popoola, O.M.., Adebayo, O.T., and Fasakin, E.A. 2008. Efficacy of aqueous extract of mistletoe Viscum album leaves as anaesthetic agent for Clarias gariepinus th broodstocks. In: Proceeding of the 4 annual School of Agriculture and Agriculture Technology, Federal University of Technology, Akure, Nigeria. Pp148-151

Rahman, M. Z., Hossain, Z., Mellah, M. F. R. and Ahmed, G. U. 2002. Effect of Diazinon 60EC on Anabus testudinus, Channa punctatusand Barbades gomonotus. NAGA The ICLARM Quarterly, 25: 8-11 
Rahman, N.Z., Geok, L.P.; Basri, M. and Salleh, A.B. 2005. An organic solvent tolerant protease from Pseudomonas aeruginosastrain K: Nutritional factors affecting protease production. Enzyme Microb. Technol., 36, 749-757.

Romero, J., Carmen, G.F., and Paola, N. 2012. Antibiotics in Aquaculture - Use, Abuse and Alternatives, Health and Environment in Aquaculture, Dr. Edmir Carvalho (Ed.), ISBN: 978-953-51-0497-1, In Tech, Available from: http://www.intechopen.com/books/healthandenvironment-in-aquaculture/antibioticsin-aquacultureuse-abuse-and-alternatives

Ross, L.G. and Ross, B. 1999. Anaesthetic and Sedative Techniques for Aquatic Animals. 2nd ed. Blackwell Science, Oxford, UK. 159 pp.

Singh, N.N., and A. K. Srivastava, 1999. "Hematology and plasma chemistry reference Intervals for cultured tilapia (Oreochomis hybrid)," J. EcoToxicol. Environ. Monitoring, 4, 137140.

Singh, R.W, Tridib, K. Rajkhowa, K.H., Victoria Chanu, M., Ayub Ali, C. Lalmuanthanga, P., Mohan, M.A., and Ayub, S. 2010. Histopathological changes caused by accidental avocado leaves toxicity in rabbits. Int. J. Res. Pharm. Sci., 4,517-520.

Skjervold, P.O, Fjaera, S.O., Ostby, P.B., and Einen, O. 2001. Live-chilling and crowding stress before slaughter of Atlantic salmon (Salmo salar). Aquacult., 192:265-280.

Stoskopf, M.K. 1993. Anesthesia. In: L. Brown, (Eds.), Aquaculture for Veterinarians: Farmed Fish Husbandry and Medicine, Pergamon Press, Oxford, England, pp. 161-168. 
Svobodova, Z, Kroupova, H., Modra, H., Flajshans, M., Randak, T., Savina, L.V., Gela, D . 2008. Haematological profile of common carp spawners of various breeds. J. App. Ichthyol., 24:55-59.

Taleb-contini, S.H., Kanashiro, A., Kabeya, L.M., Polizello, A.C.M., Lucisano-valim, Y., and Oliveira, D.C.R. 2006. Immunomodulatory effects of methoxylated flavonoids from two Chromolaena species: structure-activity relationships. Phytotherapy Research 20(7): 573575.

Taylor, P.W., and Roberts, S.D. 1999. Clove oil: An alternative anaesthetic for aquaculture. North American J. Aquacult., 61: 150-155.

Tiwari, I., and Singh, A. 2004. Metabolic changes in the Snake head fish Channa punctatus due to lattices of Euphorbia royleana,”Asian Fish. Sci., 16, 147-155.

Tyler, P., Hawkins, A.D. 1981. Vivisections, anaesthetics and minor surgery. In: Hawkins AD, ed. Aquarium Systems. London: Academic Press Inc., Harcourt Brace Jovanovich. p 248278.

Vital, P.G., 2008. Antimicrobial activity and cytotoxicity of Chromolaena odorata (Lf.) King and Robinson and Uncaria perrottetii (A. Rich) Merr. extracts. (MS Thesis) Quezon City, Philippines: University of the Philippines, Diliman. (Available at the UPD Library).

Vital, P.G., and Rivera W.L. 2009. Antimicrobial activity and cytotoxicity of Chromolaena odorata (Lf.) King and Robinson and Uncaria perrottetii (A. Rich) Merr. extracts. J. Med. Plants Res., 3(7): 511-518. 
Ubaha, G.A., Idowu, B.A,. and Omoniyi, I.T. 2012. Effects of Hypostes forskalei Schult Roem leaf extract on the behavior of Clarias gariepinus. Nature and Sci., 10(12):158-162.

Xiaoyun, Z, Mingyun, L., Khalid, A., and Weinmin W. 2009. Comparative of haematology and serum biochemistry of cultured and wild Dojo loach Misgurnus anguillicadatus. Fish Physiol. Biochem., 35:435-441.

Yildiz, M., Kayim, M, and Akin, S. 2013.. The Anesthetic Effects of Clove Oil and 2Phenoxyethanol on Rainbow Trout, Oncorhynchus mykiss at Different Concentrationsand Temperatures. Iran. J. Fish. Sci., 12: 947-961.

Table 1: Mean values of water Quality parameters recorded.

\begin{tabular}{lccccc}
\hline \multicolumn{1}{c}{ Parameter } & T0 $($ Control $)$ & T1 $(50 \mathrm{ml} / \mathbf{l})$ & T2 $(\mathbf{1 0 0 m l} / \mathbf{l})$ & T3 (150ml/l) & T4 (200ml/l) \\
\hline Temperature & 28.00 & 28.00 & 28.00 & 28.00 & 28.00 \\
$(\square$ C) & & & & & \\
DO (mg/l) & 8.70 & 8.10 & 6.90 & 5.50 & 5.10 \\
pH & 6.80 & 6.50 & 6.20 & 6.00 & 5.80 \\
\hline
\end{tabular}

Table 2. Mortality record for $C$. gariepinus juvenile Exposed to Different Concentration of C. odorata leave Extract

Conc. Log. Conc. Mortality in hr. Cum.mort \% mort. \%surv.

$24 \quad 48 \quad 72 \quad 96$




$\begin{array}{lllllllll}0.00 & 0.00 & 0 & 0 & 0 & 0 & 00 & 00 & 00 \\ 50 & 1.70 & 4 & 1 & 0 & 1 & 6 & 60 \% & 40 \% \\ 100 & 2.00 & 3 & 0 & 4 & 0 & 7 & 70 \% & 30 \% \\ 150 & 2.78 & 2 & 2 & 0 & 1 & 5 & 50 \% & 50 \% \\ 200 & 2.30 & 4 & 1 & 0 & 0 & 5 & 50 \% & 50 \%\end{array}$

Table 3. Probit kill for Clarias gariepinus juvenile exposed to aqueous extract of $C$. odorata.

\begin{tabular}{lcccccccc}
\hline Treatment & Conc. & Log. & $\mathbf{2 4 h r}$ & $\mathbf{4 8 h r}$ & $\mathbf{7 2 h r}$ & $\mathbf{9 6 h r}$ & $\%$ & \% \\
& (ml/l) & Conc. & & & & & mortality & survival \\
\hline T1 & 0 & & & & & & 0.00 & 100 \\
T2 & 50 & 1.70 & 4.31 & 4.97 & 5.60 & 6.83 & 60 & 40 \\
T3 & 100 & 2.00 & 4.32 & 4.97 & 5.60 & 6.84 & 70 & 30 \\
T4 & 150 & 2.18 & 4.31 & 4.96 & 5.59 & 6.81 & 50 & 50 \\
T5 & 200 & 2.30 & 4.31 & 4.96 & 5.59 & 6.81 & 50 & 50 \\
\hline
\end{tabular}




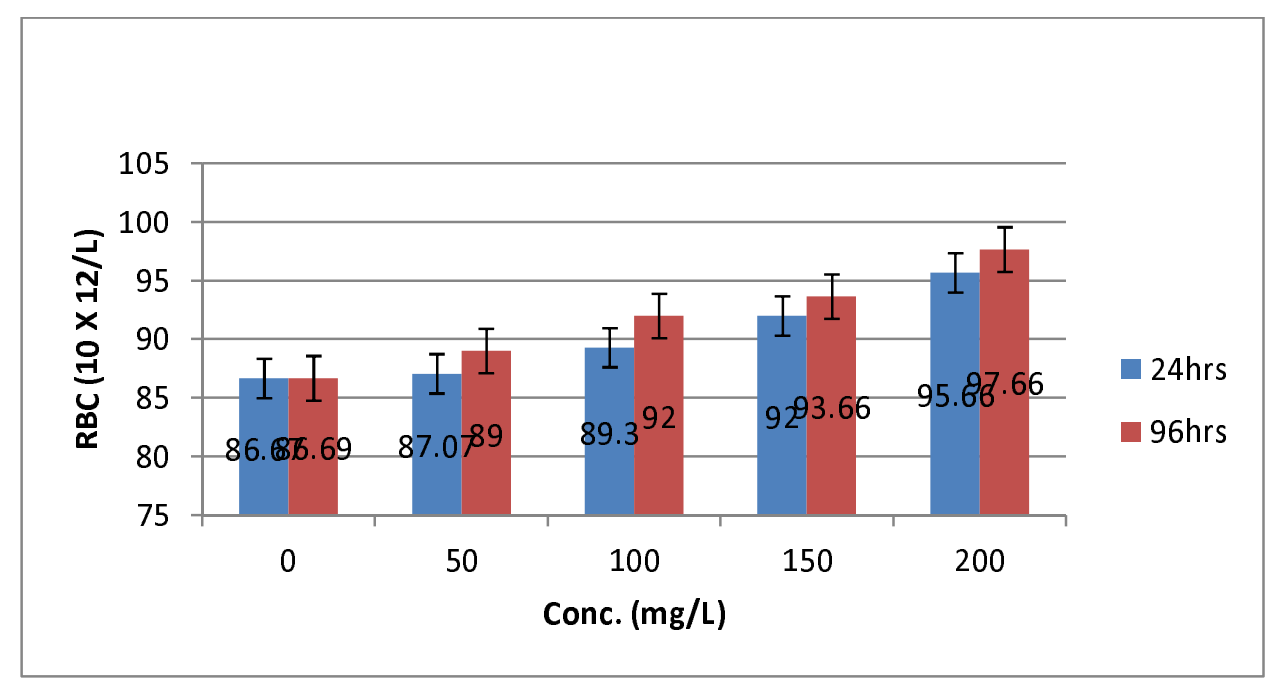

Fig. 1: Mean values of Red blood count (RBC) of C. gariepnus exposed to acute concentrations of $C$. odornata between 24 and $96 \mathrm{hrs}$.

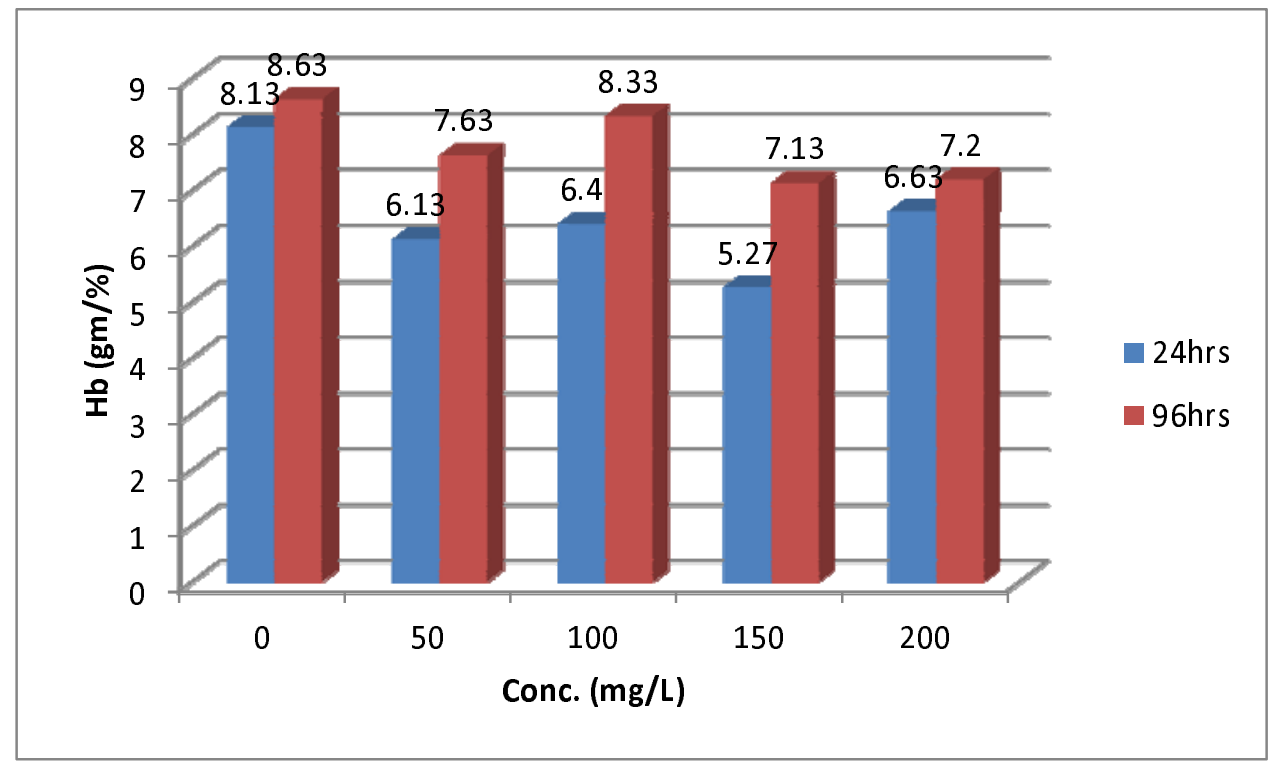

Fig. 2: Mean values of Hemoglobin content $(\mathrm{Hb})$ of $C$. gariepnus exposed to acute concentrations of $C$. odornata between 24 and $96 \mathrm{hrs}$ 
bioRxiv preprint doi: https://doi org/10.1101/181164; this version posted August 26, 2017. The copyright holder for this preprint (which was not certified by peer review) is the author/funder, who has granted bioRxiv a license to display the preprint in perpetuity. It is made available under aCC-BY-NC-ND 4.0 International license.

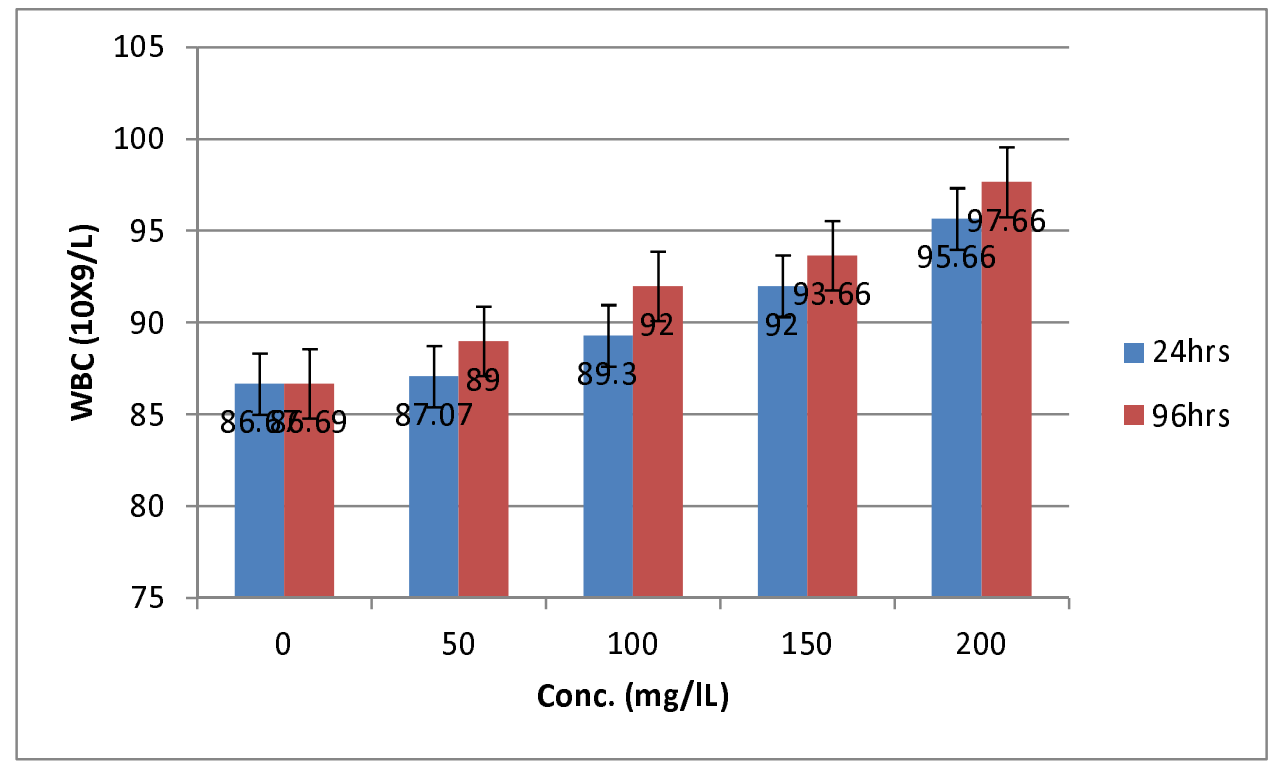

Fig. 3 : Mean values of White blood cell (WBC) of C. gariepnus exposed to acute concentrations of C. odornata between 24 and $96 \mathrm{hrs}$ 
bioRxiv preprint doi: https://doi.org/10.1101/181164; this version posted August 26,2017 . The copyright holder for this preprint (which was not certified by peer review) is the author/funder, who has granted bioRxiv a license to display the preprint in perpetuity. It is made available under aCC-BY-NC-ND 4.0 International license.

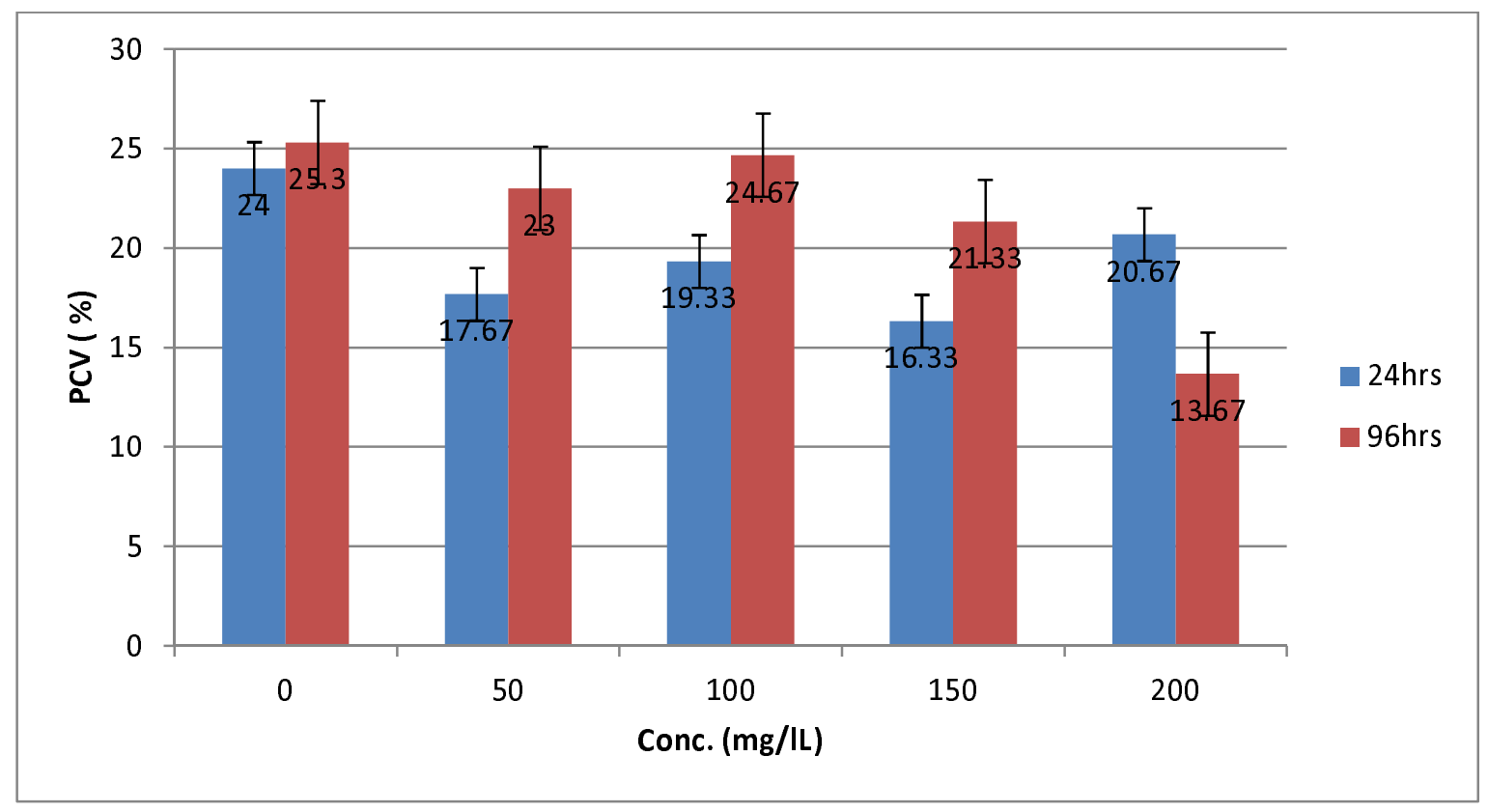

Fig. 4 : Mean values Pack cell volume (PCV) of C. gariepnus exposed to acute concentrations of $C$. odornata between 24 and $96 \mathrm{hrs}$

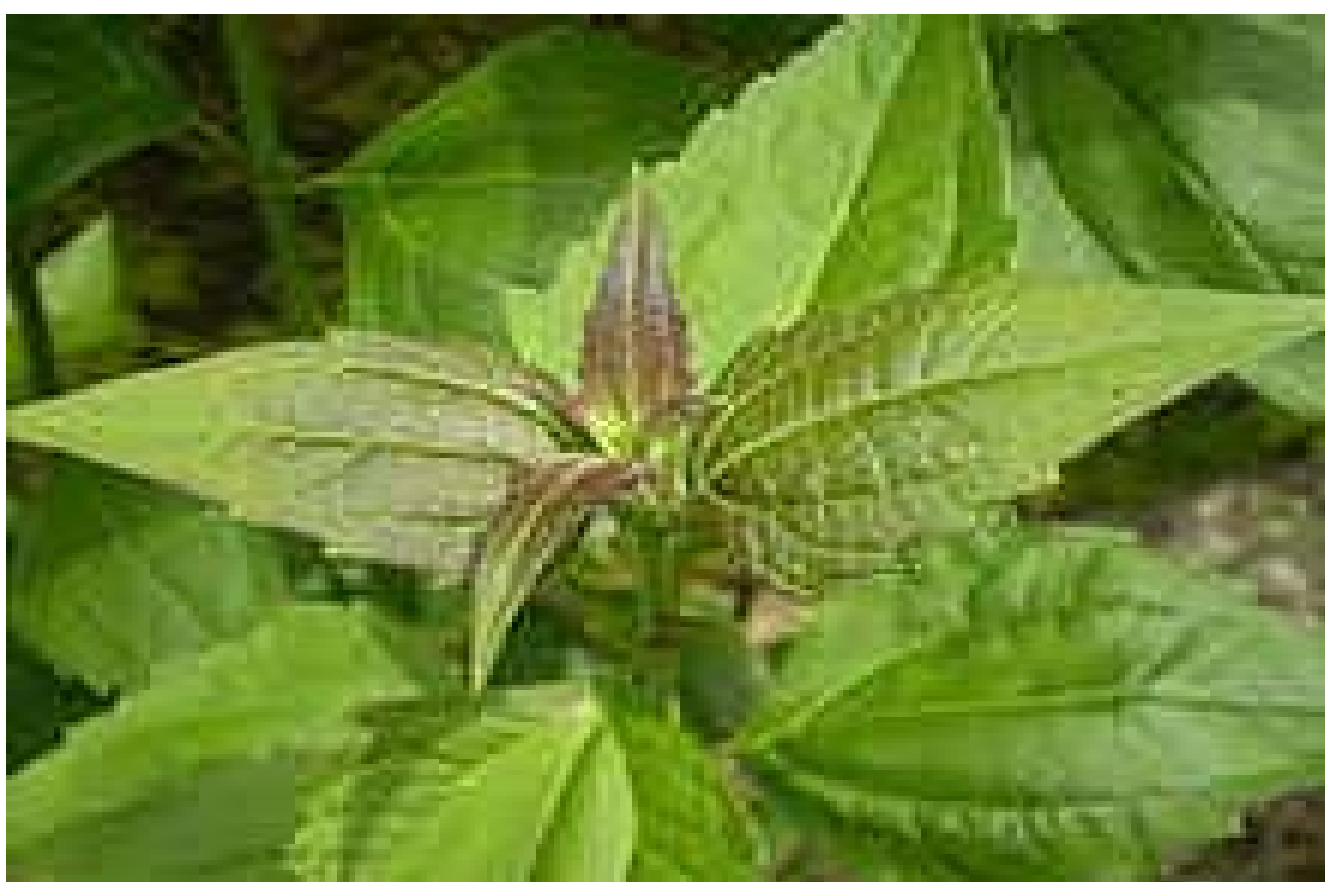

Plate 1: The leaves of Siam weed Chloromolaena odorata 